\title{
Treatment and outcome of intestinal perforation after liver transplant surgery in adults: a single- center experience
}

This article was published in the following Dove Press journal:

Therapeutics and Clinical Risk Management

31 May 2017

Number of times this article has been viewed

\author{
Jianyu Lin ${ }^{1, *}$ \\ Jing Wang ${ }^{2, *}$ \\ Peng Yue ${ }^{3}$ \\ Xingmao Zhang ${ }^{4}$ \\ Ren Lang ${ }^{4}$ \\ Yuan Wang ${ }^{4}$ \\ Chen $\mathrm{Cui}^{4}$ \\ Qiang $\mathrm{He}^{4}$ \\ 'Integrated Department, ${ }^{2}$ Patient \\ Service Center, The Affiliated Hospital \\ to Capital Medical University, \\ Beijing Chaoyang Hospital, ${ }^{3}$ School \\ of Nursing, Department of Basic \\ Nursing, Capital Medical University, \\ ${ }^{4}$ Department of Hepatobiliary \\ Surgery, The Affiliated Hospital to \\ Capital Medical University, Beijing \\ Chaoyang Hospital, Beijing, People's \\ Republic of China \\ *These authors contributed equally \\ to this work
}

Objective: Intestinal perforation is a rare complication after liver transplantation. This study was designed to calculate the incidence and investigate the outcomes of intestinal perforation in adult liver transplant patients.

Materials and methods: The clinical records of liver transplant recipients between January 2014 and June 2016 were obtained. The incidence of intestinal perforation was calculated, and high risk factors were analyzed.

Results: The mean operative time was $8.5 \mathrm{~h}$ (range: $6-11 \mathrm{~h}$ ). The mean portal vein occlusion time was $66.5 \mathrm{~min}$ (range: $58-72 \mathrm{~min}$ ), and the mean cold ischemia time was $7.9 \mathrm{~h}$ (range: 6.5-9.5 h). Four (2.7\%) patients developed intestinal perforation from 9 to 14 days postliver transplant. All perforations were single and repaired by interrupted silk sutures. Two patients uneventfully recovered, but intestinal perforation recurred in two other patients. Simple repair was undertaken in one patient, and terminal ileum resection and ileostomy were performed in the other patient. There were no perioperative deaths.

Conclusion: The incidence of intestinal perforation after liver transplantation is low. Prompt diagnosis and treatment should be carried out to reduce comorbidities and mortality.

Keywords: liver transplant, intestinal perforation, incidence, treatment, nursing

\section{Introduction}

With significantly improved quality of life and long-term survival, liver transplantation remains the effective treatment for benign end-stage liver diseases and some of the selected liver malignant tumors. ${ }^{1}$ Intestinal perforation, which has an incidence of $1 \%$ to $5.3 \%$, is a rare complication after liver transplantation. Some of the factors including abdominal surgery history, prolonged portal vein occlusion time, inadequacy of portal venous collateral circulation, long-term use of corticosteroids, and antirejection drugs were reported to be related to intestinal perforation; however, there is no definitive evidence. ${ }^{2}$ We started liver transplantation surgery at our center $\sim 10$ years ago. In this study, we calculated the incidence of intestinal perforation in adult liver transplant patients and investigated the high risk factors for intestinal perforation.

\section{Correspondence: Qiang He} Department of Hepatobiliary Surgery, the Affiliated Hospital to Capital Medical University, Beijing Chaoyang Hospital, No 8, South Gongti Road, Chaoyang District, Beijing 100020, People's Republic of China

Tel +86 I36 0I33 97I6

Fax +861056988143

Email heqiang349@sina.com

\section{Materials and methods}

\section{Patients}

In this retrospective study, the clinical data of patients who received liver transplantation between January 2014 and June 2016 at the Department of Hepatobiliary Surgery, Beijing Chaoyang Hospital, were collected and reviewed. The study protocol was 
approved by the ethics committee of Beijing Chaoyang Hospital and patients have signed an informed consent.

\section{Surgical technique}

Modified piggyback liver transplantation was performed for all patients. All the operations were performed by the same team with $>10$ years of experience in liver transplantation surgery.

Pretransplantation data of the recipients, including demographics, cause of liver disease, and Child-Pugh classification, were retrieved. Perioperative data, including cold and warm ischemia time, operative time, estimated blood loss, and blood transfusion, were recorded. Type of antirejection drugs, complications after surgery, and length of hospital stay were also analyzed.

\section{Results}

\section{Patient demographic and baseline characteristics}

During the review period, 149 patients underwent liver transplant surgery. Four (2.7\%) patients including three males and one female with a median age of 68 years (range: 58-72 years) developed intestinal perforation on days 9-14 after liver transplantation. The demographic and baseline characteristics of these patients are shown in Table 1. Of the four patients, two had hepatocellular carcinoma; and two had hepatitis B virus (HBV)-associated cirrhosis and a history of abdominal surgery.

\section{Treatment characteristics}

Methylprednisolone was given at an intraoperative dose of $500 \mathrm{mg}$ and infused at $40 \mathrm{mg}$ four times per day from postoperative day 1 (POD1) to POD4 and was tapered from POD8 to POD14 at $30 \mathrm{mg}$ daily. Meanwhile, basiliximab (20 mg) was given to all four patients during the operation and at POD4. All patients received oral tacrolimus $4 \mathrm{mg}$ twice daily from POD1 to maintain a plasma concentration of 6 to $8 \mathrm{ng} / \mathrm{mL}$.

The patients developed intestinal perforations at POD7 to POD14, and the diagnosis was confirmed by laparotomy. Perforation occurred in the jejunum in one case, the terminal ileum in two cases, and the proximal transverse hepatic flexure in one case. The characteristics of the intestinal perforations in these patients are shown in Table 2. All perforations were single with a mean diameter of $1.4 \mathrm{~cm}$ (range: $1.0-2.5 \mathrm{~cm}$ ). The perforations were repaired by interrupted silk sutures, and drainage tubes were placed. Two patients uneventfully recovered, but intestinal perforation recurred in one patient with perforation of the jejunum and in one patient with perforation of the ileum 1 week after the repair surgery.

Laparotomy revealed a perforation within $10 \mathrm{~cm}$ of the original perforation in the patient with perforation of the jejunum, which had healed. The perforation was repaired. The new perforation in the patient with perforation of the ileum had severe local inflammatory response, and terminal ileum resection and ileostomy were performed. The patients were discharged after symptomatic treatment, and there was no perioperative death. The median length of hospital stay was 26 days (range: $22-32$ days).

\section{Discussion}

Intestinal perforation is a rare complication of liver transplantation and is even less frequent in adult liver transplant recipients than pediatric liver transplant recipients. Perforation following liver transplantation is mainly due to the use of immunosuppressive agents, leading to intestinal wall necrosis, rupture, perforation, overflow of intestinal contents to the abdominal cavity, causing abdominal infection, diffuse peritonitis, toxic shock, and even death. Typical clinical manifestations such as abdominal tenderness, fever, and leukocytosis may be obscured by the use of high-dose

Table I Patient demographic and baseline data

\begin{tabular}{|c|c|c|c|c|c|c|c|c|c|}
\hline No & Gender & $\begin{array}{l}\text { Age } \\
\text { (years) }\end{array}$ & $\begin{array}{l}\text { History of } \\
\text { abdominal surgery }\end{array}$ & $\begin{array}{l}\text { Operation } \\
\text { time }(h)\end{array}$ & $\begin{array}{l}\text { Portal vein } \\
\text { occlusion time (mins) }\end{array}$ & $\begin{array}{l}\text { Blood } \\
\text { loss }(\mathrm{mL})\end{array}$ & $\begin{array}{l}\text { Infusion } \\
(m L)\end{array}$ & $\begin{array}{l}\text { Cold and warm } \\
\text { ischemia time }(h)\end{array}$ & Pathology \\
\hline 1 & $M$ & 43 & No & 6 & 58 & 300 & 0 & 8 & $\begin{array}{l}\text { HBV-associated } \\
\text { cirrhosis }\end{array}$ \\
\hline 2 & $M$ & 56 & Yes & 11 & 69 & 1,000 & 800 & 9.5 & $\begin{array}{l}\text { Hepatocellular } \\
\text { carcinoma }\end{array}$ \\
\hline 3 & $M$ & 52 & Yes & 10 & 72 & 1,300 & 1,000 & 6.5 & $\begin{array}{l}\text { HBV-associated } \\
\text { cirrhosis }\end{array}$ \\
\hline 4 & $\mathrm{~F}$ & 49 & No & 7 & 67 & 500 & 0 & 7.5 & $\begin{array}{l}\text { Hepatocellular } \\
\text { carcinoma }\end{array}$ \\
\hline
\end{tabular}

Abbreviations: $M$, male; $H B V$, hepatitis $B$ virus; $F$, female. 
Table 2 Characteristics of intestinal perforations in the study subjects

\begin{tabular}{|c|c|c|c|c|c|c|}
\hline No & $\begin{array}{l}\text { Time to } \\
\text { perforation (days) }\end{array}$ & $\begin{array}{l}\text { Location of } \\
\text { perforation }\end{array}$ & $\begin{array}{l}\text { Recurred } \\
\text { perforation }\end{array}$ & $\begin{array}{l}\text { Diameter of } \\
\text { perforation }(\mathrm{cm})\end{array}$ & Treatment type & $\begin{array}{l}\text { Length of } \\
\text { stay (days) }\end{array}$ \\
\hline I & II & Terminal ileum & No & 1.5 & Gut repair & 24 \\
\hline \multirow[t]{2}{*}{2} & 14 & Jejunum & Yes & I.0 (first time) & Gut repair (first time) & 28 \\
\hline & & & & I.5 (second time) & Gut repair (second time) & \\
\hline \multirow[t]{2}{*}{3} & 9 & Terminal ileum & Yes & $\mathrm{I} .5$ (first time) & Gut repair (first time) & 32 \\
\hline & & & & 2.5 (second time) & lleostomy (second time) & \\
\hline 4 & 12 & $\begin{array}{l}\text { Proximal transverse } \\
\text { hepatic flexure }\end{array}$ & No & 1.3 & Gut repair & 22 \\
\hline
\end{tabular}

hormones and immunosuppressive agents, increasing the difficulty of early diagnosis of the condition. At present, the diagnosis of abdominal perforation is based on abdominal computed tomography (CT) findings, as evidenced by accumulation of significant intraperitoneal fluid and changes in the nature of intraperitoneal drainage fluid. Current literature is scant on intestinal perforations, and most are anecdotal reports. We showed here that the incidence of intestinal perforation in adult liver transplant recipients was $2.7 \%$, which is consistent with previous studies reporting an incidence of $1 \%$ to $5.3 \%$ for adult intestinal perforations after orthotopic liver transplantation. ${ }^{3-6}$ The reported incidence in this study is similar to that by Xiong et al ${ }^{1}$ who studied 187 Chinese adult liver transplant recipients and detected an incidence of $3.2 \%$.

The occurrence of intestinal perforation after liver transplantation may be related to various factors including a history of previous abdominal surgery, the presence of intraperitoneal adhesions, long-term use of corticosteroids, and antirejection drugs. ${ }^{7-10}$ In our series, two patients had a history of previous abdominal surgery, and extensive intraabdominal adhesions were observed during surgery. The presence of abdominal adhesions increases the difficulty of surgery and significantly prolongs the operative time. In the study by Xiong et al, the majority of adults with intestinal perforation after liver transplant surgery had dense adhesions due to previous operation. Prolonged portal vein occlusion with inadequate collateral circulation may be another cause of intestinal perforation. ${ }^{11-13}$ There are reports of portal vein occlusion time of $>65 \mathrm{~min}^{1}$ if collateral circulation with the portal vein is not sufficient, it increases the incidence of intestinal perforation after liver transplantation. The median portal vein occlusion time in our four patients was $66.5 \mathrm{~min}$, which is comparable to the median portal venous clamp time reported by other investigators. ${ }^{1}$ However, the relationship between portal vein occlusion time and occurrence of intestinal perforation remains unknown as current existing studies are small in sample size or are anecdotal case reports.
Moreover, intraoperative and postoperative high-dose corticosteroids and immunosuppressive therapy may also contribute to the onset of intestinal perforation. ${ }^{12-15}$ Our patients received methylprednisolone, basiliximab, and tacrolimus as parts of intraoperative and perioperative management. Corticosteroids can inhibit the activities of macrophages, lymphocytes, and other inflammatory factors, but they can also stimulate gastric acid secretion and pepsin release and inhibit gastric mucus secretion, thus weakening the barrier function of the gastric mucosa. Glucocorticoids reduce the use of glucose in the body, enhance gluconeogenesis, and promote protein catabolism, leading to delayed repair of intestinal injury. Immunosuppressive therapy may also decrease microperforation repair capacity. Basiliximab is an immunosuppressive agent used to prevent early acute organ rejection after liver transplantation. There is no report on an association of basiliximab with intestinal perforation. Although it remains a possibility that basiliximab may contribute to the occurrence of intestinal perforation, given the small size of the cohort, we cannot establish such an association.

Intestinal perforation can occur in any bowel segment. ${ }^{16,17}$ Given extensive trauma caused by liver transplant surgery, the use of glucocorticoid and immunosuppressive therapy, and the serious nature of intestinal perforation, conservative treatment has a slim chance of healing intestinal perforation. Once perforation is confirmed, laparotomy should be performed and intestinal repair undertaken. As intestinal perforation is mostly single like the patients in the current series, bowel repair can often achieve the effect of cure. For multiple perforations, if they are confined to a single bowel segment, bowel resection followed by intestinal anastomosis can be considered. Recurrence of perforation may happen, and patients, nurses, and physicians should be vigilant for symptoms and signs of intestinal perforation.

There are certain limitations in the current study. This study was a single-center experience and retrospective in nature. Furthermore, the size of the study cohort is small, preventing us from reaching a clinically meaningful 
conclusion. However, the limited findings of the current study show that intestinal perforation after liver transplant surgery is a serious complication, and it remains critical that prompt diagnosis be made and early treatment be initiated for patients who have a high risk for intestinal perforation, which helps to reduce comorbidities and mortality of liver transplant recipients.

\section{Conclusion}

Although there was an extremely low incidence of intestinal perforation after liver transplantation, more attention should be paid to this complication. Prompt diagnosis and treatment should be delivered to patients if intestinal perforation was confirmed with the aim to reducing comorbidities and mortality.

\section{Disclosure}

The authors report no conflicts of interest in this work.

\section{References}

1. Xiong J, You S, He XS. Gut perforation after orthotopic liver transplantation in adults. World J Gastroenterol. 2007;13(14):2125-2128.

2. Dehghani SM, Nikeghbalian S, Kazemi K, et al. Outcome of bowel perforation after pediatric liver transplantation. Pediatr Transplant. 2008; 12(2):146-149.

3. Vilca Melendez H, Vougas V, Muiesan P, et al. Bowel perforation after paediatric orthotopic liver transplantation. Transpl Int. 1998;11(4): 301-304.

4. Peng T, Peng MH, Li LQ, et al. Intestinal perforation after combined liver-kidney transplantation for a case of congenital polycystic disease. World J Gastroenterol. 2004;10(18):2769-2771.
5. Cornejo A, Bohnenblust M, Harris C, Abrahamian GA. Intestinal perforation associated with rituximab therapy for post-transplant lymphoproliferative disorder after liver transplantation. Cancer Chemother Pharmacol. 2009;64(4):857-860.

6. Sanada Y, Mizuta K, Wakiya T, et al. Bowel perforation after pediatric living donor liver transplantation. Pediatr Surg Int. 2011;27(1):23-27.

7. Marujo WC, Stratta RJ, Langnas AN, Wood RP, Markin RS, Shaw BW Jr. Syndrome of multiple bowel perforations in liver transplant recipients. Am J Surg. 1991;162(6):594-598.

8. Caraceni P, Fagiuoli S, Wright HI, Nadir A, Van Thiel DH. Gastrointestinal complications of liver transplantation. Ital J Gastroenterol. 1995;27(1):29-39.

9. Zhou J, Ju WQ, He XS, et al. The clinical characteristics, diagnosis and treatment of early concurrent gastrointestinal leakage after liver transplantation. Chin J Surg. 2012;50:222-225.

10. Soubrane O, el Meteini M, Devictor D, Bernard O, Houssin D. Risk and prognostic factors of gut perforation after orthotopic liver transplantation for biliary atresia. Liver Transpl Surg. 1995;1(1):2-9.

11. Kirby RM, McMaster P, Clements D, et al. Orthotopic liver transplantation: postoperative complications and their management. Br J Surg. 1987;74(1):3-11.

12. Yamanaka J, Lynch SV, Ong TH, et al. Surgical complications and longterm outcome in pediatric liver transplantation. Hepatogastroenterology. 2000;47(35):1371-1374.

13. Ferraz-Neto BH, Sakabe D, Buttros DA, Resende MB, Afonso RC. Portal vein aneurysm as late complication of liver transplantation: a case report. Transplant Proc. 2004;36(4):970-971.

14. Bonatti $\mathrm{H}$, Muiesan $\mathrm{P}$, Connelly $\mathrm{S}$, et al. Hepatic transplantation in children under 3 months of age: a single centre's experience. J Pediatr Surg. 1997;32(3):486-488.

15. Pungpapong S, Alvarez S, Hellinger WC, et al. Peritonitis after liver transplantation: incidence, risk factors, microbiology profiles, and outcome. Liver Transpl. 2006;12(8):1244-1252.

16. Yamanaka J, Lynch SV, Ong TH, Balderson GA, Strong RW. Posttransplant gastrointestinal perforation in pediatric liver transplantation. J Pediatr Surg. 1994;29(5):635-638.

17. Kwon HJ, Kim KW, Song GW, Hwang S, Ha HK, Lee SG. Uncommon gastrointestinal complications after liver transplantation: radiologic findings and clinical features. Acta Radiol. 2013;54(1):1-7.
Therapeutics and Clinical Risk Management

\section{Publish your work in this journal}

Therapeutics and Clinical Risk Management is an international, peerreviewed journal of clinical therapeutics and risk management, focusing on concise rapid reporting of clinical studies in all therapeutic areas, outcomes, safety, and programs for the effective, safe, and sustained use of medicines. This journal is indexed on PubMed Central, CAS,
Dovepress

EMBase, Scopus and the Elsevier Bibliographic databases. The manuscript management system is completely online and includes a very quick and fair peer-review system, which is all easy to use. Visit http://www.dovepress.com/testimonials.php to read real quotes from published authors. 